\title{
Witchcraft, witch doctors and the fight against 'superstition' in nineteenth-century Germany
}

\author{
Nils Freytag ${ }^{1}$
}

The Most Esteemed Royal Government may commonly find these beliefs in witches and ghosts, in the devil and his supposed manifestations everywhere among the educated and the uneducated, in the province of Prussia and in all others of this state and all states. Even in most recent times, witch-hunts have occurred in the Regierungsbezirk [administrative sub-unit within a Prussian province] of Coeslin, in the area of Bütow and, before that, near Peplin and in the Marks, as documented examples of the difficulties of exterminating a madness perpetuated and continued by tradition.

The above quotation is taken from a lengthy report written by von Platen, the Landrat or administrative head of Neustadt district, West Prussia, to a government minister in $1836 .{ }^{2}$ It concerned the murder of Christina Ceinowa, a mother of six, who had long been suspected of witchcraft by her neighbours. The widow had been drowned in the waters off the Prussian Baltic peninsula of Hela on 4 August 1836. She had received terrible mistreatment at the hands of eight fishermen from the small village of Ceinowo, led by the so-called witch doctor Stanislaus Kaminski, who had made them subject her to a water test. The fishermen were absolutely convinced that because of her bewitchment one of the villagers was actually possessed by the devil. Because of this, they had imprisoned Ceinowa, a lay healer, on the day before, beaten her with clubs, tied her up and thrown her into the Baltic Sea. When she stayed afloat for some time, probably because of her voluminous skirts, their suspicions were confirmed: Christina Ceinowa really was a witch, and obviously responsible for the grave illness of the fisherman Johann Konkel. The fishermen involved gave her a day and a night to take back the bewitchment. When the allotted time was up and Konkel was still no better, they once again threw her into the sea, where she finally drowned while Kaminski stabbed her.

It was the Prussian Minister of the Interior, Rochow, horrified at reading this, who underlined the words and phrases in the above quotation. Additionally, he marked the passage by a large question mark in the margins. $\mathrm{He}$ 
also documented his astonishment at passages reporting widespread superstition throughout the Prussian realm - one was, after all, living in the nineteenth century. In no way did the enlightened Rochow agree with the Landrat's summary regarding the widespread and commonplace belief in witchcraft, ghosts and the devil. Instead, he sought alternative explanations for the gruesome murder. As will become evident, his responses to the incident need to be seen within the context of the religious situation at the time. Prussia had long been an officially Protestant state. Yet by 1836 a sizeable minority (around 40 per cent) of the Prussian population was Catholic, most of whom lived in Silesia and former Polish territories annexed in the previous century, and in the provinces of Rhineland and Westphalia annexed in 1815. Ceinowo, now part of Poland, was one such Catholic community.

The measures taken by Rochow are fortunately documented in the files of the Prussian Ministry of the Interior kept at the Berlin Geheimes Staatsarchiv (Prussian State Archive). This particular archival material complements a wide range of sources aiding us in researching attitudes regarding the belief in witchcraft during the nineteenth century. As well as examining the archival material kept by the state administration and official church records, in which administrators and clergy stated their opinions, it is also helpful to consider the opinions of physicians and journalists regarding popular beliefs. After all, it was a news report that initially made the Prussian Ministry of the Interior aware of the Hela murder. Sources deriving from within the witch-believing public are much rarer, but are still extant in written charms, petitions addressed to the administration, and eyewitness accounts from patients explaining the reason for their medical choices. One more class of material needs to be considered: anti-superstition literature. Books and pamphlets railing against popular beliefs were published throughout the nineteenth century, and contain many useful pieces of information. As to their efficacy, it appears more likely that rather than reducing the sum of 'superstition' they kept public interest in its subject going - even among those sections of the population who were the target of their 'improving' discourse.

Research on the continuation of witchcraft beliefs after the end of the witch trials is still in its infancy among German historians. Recently, there have been some innovative impulses in researching the persistence or reemergence of magic in the nineteenth century. Here, so-called superstitious practices and beliefs are placed within their social and cultural context and analysed according to modern patterns of interpretation. ${ }^{3}$ However, the results are, as a whole, quite meagre, a summary that can be repeated regarding recent folklore research as well, even though the discipline has a long and influential tradition of investigation into witchcraft and superstition. Many nineteenth- and early twentieth-century German folklore and antiquarian studies contain references to relevant contemporary occurrences. 
Early folklorists interpreted 'superstition' mainly as a relic of pagan or medieval beliefs that were already widely submerged. Even in the twentieth century, folklorists were using their material to prove the timeless and mythical continuity of pre-modern ideas. ${ }^{5}$

All these various sources demonstrate that the belief in witchcraft remained widespread during the nineteenth century, and was consequently considered a virulent problem by the authorities. Since the age of Enlightenment, witchcraft had largely ceased to be considered a probable cause of misfortune in educated circles, but outside these circles it remained a common explanation for many incurable diseases and sufferings. Even if the religious understanding of disease was in all practical aspects supplanted by a medical and scientific one, we can severely doubt whether Heinz Dieter Kittsteiner's theory about the internalization of evil in the era of Enlightenment holds true outside educated society. ${ }^{6}$ The Catholic Church and state administration were confronted time and again with petitions and queries regarding witchcraft and magic, which contain many differing views and interpretations. The opinions of the acting parties will be the subject of the following discussion, which analyses the intentions of the medical profession and the state administration, the reaction of the Catholic Church and clergy, and the views of the people at the heart of such events as the Ceinowa incident.

\section{Superstition or illness? Interpretations by the state and the medical profession}

The authorities' campaign for the enlightenment of the population continued far into the industrial era, often accompanied by journalistic efforts. The state administration subtly but consistently co-ordinated its campaigns against the belief in witchcraft, magic and ghosts with the Catholic Church authorities, assigning active roles to clergy, teachers and doctors. The Hela murder is a very good example of this. Although the eight fishermen involved and their ringleader, the lay healer Stanislaus Kaminski, who was known to the Prussian authorities from related incidents, were severely punished, the main concern in far-away Berlin was the extermination of the witchcraft superstitions that had governed the fishermen's actions. Although in the short term the preferred instrument of this fight was suppression by means of censorship, bans and medical intervention, the Prussian state would, in the long run, combat superstition by means of better education, religious instruction and the popularization of medical knowledge, especially among the younger generation. Mid-range efforts included the improvement of communications, among which the Prussian ministerial officials during the Vormärz era counted the construction of roads. These made remote villages like Ceinowo on the Baltic peninsula of Hela much more easily accessible and served to include them into the economy at large. Local government in the nearest 
administrative centre Danzig saw an important cause for the Ceinowa murder in the fact that the Ceinowo economy was precariously reliant on fishing. The economic situation in the village was said to be "meagre and highly precarious. These unfortunate circumstances have much contributed to severely retarding civilisation, as people are far too impecunious to avail themselves of its blessings'. The main consequences for the villagers consisted of an increased presence of the state in their midst. This was of primary importance for Rochow. In 1836 extra money was assigned to hire an additional constable as well as to improve schooling, which was perceived to be highly deficient. ${ }^{8}$ The state representative in Ceinowo, the village mayor, Jacob Trendel, who believed in witchcraft, was replaced; the Prussian state would not tolerate unenlightened civil servants. ${ }^{9}$ However, the correspondence between Rochow and his colleague Altenstein in the Kultusministerium (Ministry of Culture and Education), shows that increased policing took absolute precedence over improving education. ${ }^{10}$

Yet the overriding perception was still that education was the most powerful instrument for the containment of superstition alongside religious edification and admonition. Thus Altenstein insisted on urging the Catholic clergy to fight the 'delusional' beliefs in witchcraft. For a long time, the curriculum in Prussian schools had concentrated less on imparting progressive knowledge and education than on discipline and obedience. Again, it is no surprise that the typical laments about the lack of education as reason for the continued belief in witchcraft was repeated and confirmed again and again - a verdict that even the Catholic Church might have shared. ${ }^{11}$

In Ceinowo, things were out in the open. Those involved in the deadly water test were charged with murder. In most cases, however, manifestations of belief in witchcraft were not considered capital offences. In the opinion of Prussian legislation, superstition was mainly caused by stupidity and lack of education, so the state was more worried about the cynical exploitation of the superstitious by cunning-folk and the like. Criminal charges of fraud were the standard procedure in these cases, and suspects were, as a rule, found guilty. Additionally, the charge of grober Unfug or 'criminal mischief' (\$360, no. 11 in the penal code of the German Reich from 1871) was also used to combat the practice of magic. The offence was initially primarily employed to suppress various Social Democrat political intrigues. It gained its relevance regarding magical practitioners from a decree issued by the Prussian Ministry of the Interior on 14 October 1873, which declared 'the encouragement of superstition' an offence punishable by a fine of 150 Reichsmark or imprisonment. ${ }^{12}$

Prussian medical authorities, and many doctors in their wake, tried to use their medical and scientific world-view to rationalize the irrational and to explain 'abnormal' beliefs increasingly in terms of mental illness. At least the same importance was accorded to keeping peace and order. Public security was the primary concern, for example, when in 1837 the somnambulistic 
visions of ten-year-old Peter Hennes of Koblenz came to the attention of the authorities. The boy had seen not only the apostles but also the Devil and drew large crowds in the city, which caused the Koblenz police sergeant to perceive him as a threat to 'Ruhe und Ordnung' ('peace and order'). In order to get the bottom of these incidents and to control the crowds, the sergeant set about questioning numerous witnesses. One of them was the Koblenz doctor Richter, who diagnosed the boy as displaying 'artificial' somnambulism. ${ }^{13}$ Yet the psychological interpretation of such beliefs in witchcraft and the Devil was cited increasingly often throughout the century and had its roots among the first mesmerists, who sought to explain everything - even early modern witch-hunts - in terms of animal magnetism. ${ }^{14}$

Throughout the nineteenth century, as the medical profession established itself, religious healers were increasingly relegated merely to consoling and comforting the sick rather than actually diagnosing and curing. ${ }^{15}$ A central decree for the Rhine province dated 29 September 1827, which the Prussian civil servants were subsequently admonished to strictly enforce, banned all forms of pastoral medical therapy. Clergymen in violation of this law were threatened with severe punishment. ${ }^{16}$ However, the practice of following and administering this decree was discontinued after some time. In 1841, the chaplain of the Siegburg mental institution, Reverend Löhr, had to ask the Cologne Generalvikar to intercede against the practice of exorcising mentally ill women who thought themselves witches, and to have them immediately consigned to the lunatic asylum. ${ }^{17}$ This is proof of the well-aimed efforts by the medical administration and individual doctors to disassociate illness from its interpretation within the context of Christian religion. Using the charge of superstition in this context demonstrated the advance of secularization and modernization in the understanding of 'superstition'. The incident is additional proof of the many-faceted use of this term, the use of which helped Prussian civil servants and physicians to repeatedly reassure themselves of its consistent definition and their shared point of view. From this perspective, belief in miracles and witchcraft gave reason to repeatedly classify these incidents among similar occurrences, thus providing them with a semblance of a historical context and divesting them of their religious significance. ${ }^{18}$

Quite obviously, the administrative and medical view of the closely connected belief in witchcraft and the Devil changed visibly during the nineteenth century. While at the beginning of the century, exorcism caused official concern only when it became a public spectacle, at the end even its tacit toleration was frowned upon. While earlier the high number of possessed or spiritually healed people gave cause for scandal, later on even the mere fact of an incident of exorcism or Überlesen ('reading over'; the reading of religious text in order to cure illness or possession) would cause public offence and ridicule. ${ }^{19}$ Such activities were perceived as a sign of rural Catholic retardation in the eyes of the liberal bourgeoisie. With the beginning of the 
Prussian and German Kulturkampf this ostracizing discrimination joined wider controversies regarding Weltanschauung. This point of view was widely accepted among Prussian civil servants and led to many conflicts with the Catholic Church. Denominational motives were certainly behind some of these attacks. Members of the Evangelischer Bund zur Wahrung der deutschprotestantischen Interessen (Evangelic Association for the Realization of German Protestant Interests) and journalists associated with them often accused the Papacy and the Jesuits of concertedly promoting the belief in witchcraft. This propaganda may lie at the root of the persistent legend that early modern witch-hunts and the belief in witchcraft had been an almost exclusively Catholic phenomenon.

\section{Between secret investigation and toleration: variants in the attitude of the Catholic Church}

The persistence of traditional forms of piety, like the belief in witchcraft and the Devil, which were sporadically highlighted and lamented by the enlightened press forced church authorities into action. ${ }^{20}$ Banning religious 'heresies' and their scandalous consequences was an important issue for the Catholic Church throughout the century. The Cologne Generalvikariat in particular took careful note of any breaches of Catholic norms, labelling them 'religiöse Mißbräuche und Umtriebe' ('religious abuses and subversive activities'). This blanket term was used to describe and denounce religious activities as varied as the reading of supposedly superstitious tracts, the use of spiritual therapies like exorcism and miracle cures, and the belief in witchcraft, hauntings, stigmatizations and other so-called false pieties. ${ }^{21}$ While all ideas and practices associated with these beliefs were frowned upon as violations of the norms and ideas of the official Catholic Church, on their own they were not usually serious enough to draw the interest of the archbishopric. More important to the Cologne Generalvikariat than the violations themselves were instances when the local clergy supported or even instigated these incidents, or when the events drew conspicuously large crowds. ${ }^{22}$ It is important to note that the definition of what were legitimate and illegitimate activities was never clearly stated in the first place and varied widely, depending on time and circumstance.

The difficulties of explaining the distinction between miracles and superstitions were quite apparent in the practical handling of the belief in witchcraft. Outside the Catholic Church itself, all efforts to distinguish clearly the two fields of belief met with failure. ${ }^{23}$ The Church and the Rhineland clergy were constrained by the demands for peace and order from the Prussian authoritarian state, which insisted on the medical and scientific interpretation of illness on the one hand, and the needs of many practising Catholics who still adhered to traditional religious ideas on the other. For 
the Catholic Church, this meant constant rivalry in its relations with medical science and state-approved physicians and, at the same time, a loss of its normative function. An understanding of natural science lowered the probability of a miracle - even if it was, in principle, still possible - and incited general doubts about the truth of religious teachings. In addition, pressure from the press, which was extremely critical of any religious deviation, further constricted the radius of action for the Catholic Church. Nevertheless, the leadership of the diocese did possess several instruments with which to react to religious deviations and miraculous incidents. For example, secret investigations of odd occurrences and miraculous manifestations were conducted - 'at first quietly and without causing a stir' as Church sources repeated time and again. ${ }^{24}$ Public investigations ran the risk of attracting the attention of the newspapers, which the church wanted to avoid at all cost. The diocese tried to quell public perception that official recognition of the strange and miraculous was certain and imminent.

The usual practice throughout the nineteenth century was to select expert clergy to investigate miraculous affairs. ${ }^{25}$ In difficult cases, when several of the local clergy had already stated their agreement on the reality of events, the leadership of the diocese itself decided to intercede. This occurred in Giesenkirchen in 1890 when the visions of the probably epileptic 33-year-old Gertrud Püllen attracted the strong backing of the local clergy. The case interwove the belief in miracles, diabolism and witchcraft. She experienced apparitions of both the Virgin Mary and the Devil, who took regular turns to communicate with or through her. While possessed by the Devil she would blaspheme, as the embarrassed author of a report on these events put it, against 'the present clerics, the dirty Nazarene and, in a way that doesn't bear repeating, the Mother of God'. This was often accompanied by the vomiting of coins, needles and steel nibs in addition to the more usual bloody bile. ${ }^{26}$ A local mystic, whose visions confirmed Püllen's ecstatic outpourings, bolstered her credibility and intensified her influence on the population. ${ }^{27}$ The local clergy composed a joint petition to the Cologne Archbishop, urging his consent to exorcise her. However, the woman died before the canon, suffragan bishop and later Archbishop of Cologne, Antonius Hubert Fischer, who had speedily hurried to Giesenkirchen, could complete his report. ${ }^{28}$ Even if such occurrences were imbued with an aura of the extraordinary that caused public scandal in some sections of the population, they also served to prove the interconnection between Christian belief in miracles and the certainty of Evil that extended even into the rank and file of the Catholic clergy. Still, there were phases when the Catholic Church reacted with caution and restraint, leaving things to run their natural course, especially during the German-Prussian Kulturkampf, when the toleration of miraculous apparitions of the Virgin Mary may certainly have been motivated by denominational politics. ${ }^{29}$ 
Although many of the local clergymen tried to avoid exorcism, they were repeatedly forced to appeal to the church authorities. They were regularly confronted with pleas for help from their parishioners to aid with curing people and animals by Überlesen or 'reading over' the patient when orthodox medical alternatives proved inadequate. ${ }^{30}$ This highly popular religious therapy was used against both possession and bewitchment, and was not only employed by the clergy. In 1825, in the small village of Walldorf (Kreis Bonn), a witch doctor named Heinrich Küchen stood in for the parish priest, Jacob Schmidt, who had refused to treat an allegedly bewitched child. ${ }^{31}$ Owing to the popularity of such spiritual therapies, and because of a particular query by the Neukirchen parish priest Friedrich Christian Philipps, in 1831 the Cologne Generalvikariat was forced to outline its own views about the use of exorcism in cases of bewitchment. Under the condition that the Kreisphysikus (district medical doctor) was consulted, the Generalvikariat defined exorcism 'as a psychological measure perhaps not without its successes, but contrary to the declared intentions of the church, as they would hand justified cause for censure and ridicule to the unbelievers and heretics of our enlightened times'. ${ }^{32}$ In his answer, the epochal change towards favouring medical explanations is also present, as mental therapy in the Siegburg asylum (founded in 1825) was ultimately advocated. ${ }^{33}$ Nevertheless, sometimes when patients, who believed themselves bewitched, were discharged from the asylum as incurable, their families once again sought the clergy to 'read over' their relatives. $^{34}$

The position taken by the Generalvikariat assured the unquestioning acceptance of medical authorities and their responsibilities in order to avoid immediate interference from the Prussian state in internal Church affairs. Yet when clergymen clearly and unmistakably denounced the belief in witchcraft and miracles, they had to expect problems from below. When, for example, the priest of the Aachen parish of St Foilan, preached from the pulpit against a miracle healer, the next morning he found himself confronted with a graphic reprimand in the shape of a dead cat nailed to his house. ${ }^{35}$ As this clergyman was the widely known and highly important Aachen city dean and arch-canon Johann Theodor Mürckens, this incident serves to prove the fact that the anger of the population was not tempered in the face of high-ranking personages within the Church.

The demand of the state authorities for the immediate removal of superstitious clergymen from their parish duties put Church authorities in a precarious situation, as large parts of the clergy evidently tolerated or even encouraged such ideas and practices. The archival sources from the Cologne Generalvikariat show that some clergy actively participated in the popular discourse on witchcraft, possession and mystical phenomena, especially monastic clerics like Jesuits, Capucins, Redemptorists, and, in the Rhine province, Franciscans. ${ }^{36}$ Parish priests in the diocese who did not toe the official line 
and publicly voiced their belief in such phenomena were subject to severe punishment from the Church authorities. ${ }^{37}$ It is important to note that such clergy understood that the belief in witchcraft and miracles served to nourish traditional piety, which could be channelled into other popular expressions of faith such as the veneration of the Sacred Heart.

Education and admonition were primary among the preventative measures pursued by the Church. While thorough studies constituted the basis for a well-educated parish clergy, later additional education within the dioceses served to build upon these foundations. ${ }^{38}$ Numerous sources from parish archives show how far into the century the fear of the uncertainties of everyday life was expressed in terms of magic and witchcraft. As a consequence Catholic Church admonitions were rather common. In the autumn of 1837, for example, the wife of the bargeman Goswin Schneider of Remagen was ostracized as a witch and physically abused. The Remagen population accused the woman of having bewitched a sick child. To resolve the tensions in the town the Prussian authorities relied on the admonishing influence of the experienced parish priest of Remagen, Johann Joseph Windeck, who was told to calm his parishioners down. Windeck's role was all the more important because the representative of local authority in the shape of police constable Klein had utterly failed his official duties by taking part in the persecution of Schneider. ${ }^{39}$

Did the official Ultramontane Church succeed in controlling and directing divergent Catholic practices and beliefs? This is an important question, not only for current research, but also to help contextualize the claims of nineteenth-century commentators who accused the Catholic Church of reinvigorating the belief in witchcraft. ${ }^{40}$ It is absolutely necessary to remind oneself of the difference between traditional Catholicism and Ultramontanism. Even if Ultramontanism supported traditional forms of piety, its utopian goals were ultimately anything but traditional. Of course, its intentions were nurtured by the retroactive utopia of re-establishing old balances of power by modern means. Even beyond the middle of the century it was still obvious how narrow the radius of action was for clergymen trying to contain and suppress traditional forms of piety, as in conflicting situations they frequently had no choice but to accede to the wishes of their parishioners.

\section{Internal views: warding off fear, illness and crises}

Historians' attempts to understand the internal perspective of those who believed in witchcraft and the Devil during the nineteenth century are fraught with several problems. In the first place, there is the issue of source material. There are relatively few sources that derive directly from the pen of those actually involved in witchcraft disputes. Much research is still needed in this area. What we find in Catholic Church archives are numerous statements on 
the subject by those clergy who played secondary roles in disputes. Miracle healers and lay exorcists certainly publicized testimonies from grateful patients to document their success rate, but we rarely hear directly from those patients. Some sources, however, do bring us closer to the 'popular' voice. There are, for example, documents in which people apply for dispensation from the bishopric to conduct exorcisms for family members. Investigations by the official Church against clergymen charged with exorcism would also quite frequently contain testimonies from parish members stating their belief in witchcraft and the Devil.

During the first decades of the Prussian rule in the Rhine province from 1815 onwards, the cultural distance of many civil servants from the many customs of the Rhine area help explain the reason for numerous bans and prejudices. Lack of cultural comprehension could culminate in accusations of superstition by the new rulers. ${ }^{41}$ They were not at all used to such Rhineland and Westphalian customs as the Gänsereiten or Gänsehauen, which concerned the ritual clubbing to death of live geese from horseback, a custom reserved exclusively for servants using their masters' horses in a classic reversal of social roles. Neither did they look favourably on the lavish wakes called Reuessen und-trinken, the Gebehochzeiten - sumptuous weddings that often brought the participating families close to ruin, and the wedding custom known as Brautfangen ('bride-catching'). Attempts were made to suppress such 'unenlightened' practices. ${ }^{42}$ Further considerations of medical policy and public order as well as the enlightening intentions of the Prussian administration led to frequent bans of such customs by the authorities. However, cultural and denominational distance must have played a prominent role and should not be underestimated, especially as it was used for auxiliary argumentation culminating in the handy and catchy accusation of superstition. Even if exorcists and witch doctors who spread the belief in witchcraft were seen as damaging, superstitious and dangerous in the official verdict, this view only prevailed very haltingly among the local population.

When, in 1818, a letter bearing a false address was passed to the Cologne Oberpräsident, Solms-Laubach, denouncing the 'superstitious' ringing of church bells to turn away thunderstorms in the municipality of Wichterich, the chief administrator reacted immediately in having the abuse investigated and banned. ${ }^{43}$ The Oberpräsident correctly connected this custom of 'Gewitteroder Wetterläuten' with traditional methods of warding off lightning, demons and witches that were banned in the archbishopric of Trier around 1783 by the last Trier Elector and Archbishop, Clemens Wenzeslaus. ${ }^{44}$ Despite such prohibitions it should come as no surprise that church bells continued to be rung in the Rhine province during the nineteenth century to ward off witches as well as thunderstorms.

Behind such beliefs, which were widely denounced as expressions of irrationality and pre-modern thinking, we may find far more rationality than 
is evident at first sight. Consulting a witch doctor after numerous medical professionals had been consulted and failed to offer a solution can be seen as a rational act if we assume health to be a forward-looking value, in so far as it helps assure a better future. ${ }^{45}$ Additionally, it is of course an active and independent act to undertake a journey by one's own choice in order to find relief for a disease deemed incurable. This is a quite rational decision - an attribute of 'superstition' denied by all enlightened administrative statements. The Hela case from 1836 demonstrates the point. The sick fisherman, Johann Konkel, had little choice but to consult the cunning-man Kaminski for his help as no doctor had yet settled near the remote village. Only when Kaminski's therapeutic means did not meet with success did the suspicion of witchcraft lead to an act of 'superstitious' physical violence. It is interesting, though, that the brute force of the highly inebriated villagers was enacted against none other than a potential rival of the lay healer Kaminski. ${ }^{46}$ The questioning of some villagers and the 23-year-old village mayor, Trendel, turned up the fact that everyone thought the influence of witches on the weather, fishing catches and the health of the villagers a self-evident truth. In addition, everyone thought that the easily excitable Christina Ceinowa was a witch who could induce as well as cure all kinds of illness. ${ }^{47}$

Belief in witchcraft and in warding off evil personified was not only rooted in a long and varied tradition of medical diagnosis and cure, it also remained a common source of resolving a multitude of fears and personal and communal crises. ${ }^{48}$ Emotions of fear and guilt were part of everyday life for Catholic men and women, as research on contemporary autobiographical sources has suggested. These emotions culminated in the fear of hell as punishment for religious and moral misbehaviour. ${ }^{49}$ Trying to find a deeper meaning behind events strengthened the idea of illness as a punishment from God. But new fears were also integrated into traditional patterns of interpretation. An overt expression of this phenomenon was the common refusal to use the increasingly ubiquitous steam trains. Popular prejudices against the railways, contemporary symbol of progress and facilitators of industrialization sometimes culminated in actual phobia. The trains, spewing sparks and steam, were thought by some to be a fiendish manifestation. In Baden, for example, it was said that people believed that the Devil took one passenger at each station as his reward. ${ }^{50}$

Protection from the evil influences of the Devil, ghosts and witches, or the warding off of general bad luck remained important to a significant section of the population throughout the century and beyond, as the impressive collection of scrapbooks and loose papers from the vicarage of Konfeld (Trier Diocese) shows. ${ }^{51}$ This anthology, which contains numerous prophylactic charm formulae, was probably confiscated and kept safe by the parish priest around the beginning of the nineteenth century. It seems to have been compiled by several literate authors from different early modern magical 
texts. One protective formula repeatedly found in this collection is entitled, 'To banish evil spirits and evil people from the house and the stables':

Bethzairle and all evil spirits, spirits human and airy, watery, seeds of fire and earth and all ghosts, I, N. forbid you my bed and the beds of my children, I forbid you in the name of God my house, stables, barns, the flesh and blood of myself, my wife and my children, our bodies and souls; I, N., forbid you all holes, even nail holes, in my house, stables, barns, everywhere around my house, until you ... all the little hills and empty all the little brooks, count all the little leaves on the trees and all the stars in the heavens, until the dear day comes unto us when the Blessed Virgin Mary bears her second son. +++ These I forbid you in the name of the most holy trinity God Father + Son + and Holy Ghost + Amen. ${ }^{52}$

It is remarkable that this formula aims to put witches, ghosts or devils to never-ending work in order to keep them eternally busy and unable to fulfil their evil intentions. The formula was not meant to defeat evil but merely to keep it at bay, while the speaker asked for divine support and warding off of evil by calling it by its name. The continuity of such ideas is proven by the existence of Schutzbriefe, protective letters purporting to be written by Jesus, the Virgin Mary, or various saints, which were supposed to protect their bearer by their mere presence. They were enormously popular during the First World War. ${ }^{53}$ Frightening or miraculous events like stigmatizations, ecstatic visions or accidents of fate not only strengthened the belief in the work of personified evil but also the willingness to use exorcism to banish it. It was not just in rural areas that such beliefs found expression, but also in towns and cities such as Berlin, where, in 1849, the satanic visions of eleven-year-old child prodigy Luise Braun electrified the populace as much as the revolutionary instability gripping the place..$^{54}$

Only a few of the social and societal functions of witch-hunts were still extant in the nineteenth century. In Ceinowo a medical rival and outsider was reinterpreted as a witch and destroyed with the help of several villagers, although state and Catholic Church had already considerably narrowed the radius for magical interpretations of personal crises and threats. Historians of the French Annales School have shown us the importance of 'long-persistent structures' in society. These structures have been found especially in the context of pre-industrial rural culture and manifested in the belief in witchcraft. This supposition of 'long persistence' corresponds partially with folkloristic research into superstition during the nineteenth and early twentieth centuries, which sought to identify the belief in witchcraft as a relic of Germanic and pagan practices. This notion is also hinted at in the concept of the 'Überhang traditioneller Normen' ('overhang of traditional norms') applied to the rural world of the Kaiserreich (1871-1918). ${ }^{55}$ However, this interpretation is only one potential perspective on the practices that contemporaries subsumed as superstitious. The extent to which this was an exclusively rural phenomenon 
remains to be assessed by means of extensive surveying of sources relating to urban societies such as newspapers. Beside the continuity and the extension of presumably pre-modern ideas into modern times, the question of change in these ideas is important, especially as an evolution of the belief in witchcraft can be proven when traditional ideas mingled widely and variously with the realities of modern life. A profound change in dealing with the belief in witchcraft, however, cannot be discerned for the nineteenth century. Instead of the public and judicial fight against witchcraft typical of the early modern age, a private and predominately rural struggle against alleged witches prevailed during the nineteenth century. After the secular and ecclesiastical authorities penalized these ways of dealing with witch-inspired misfortune, its crises and its conflicts, and while scientific medicine constantly gained influence, only extraordinary eruptions of these beliefs can be found in the sources so far studied, while the probably much more common suspicions and slanders of witchcraft only rarely found their way into the public sphere.

\section{Notes}

1 The following is based on Nils Freytag, Aberglauben im 19. Jahrhundert. Preußen und seine Rheinprovinz zwischen Tradition und Moderne (1815-1918) (Berlin, 2003). The following abbreviations are used: LHAK (Landeshauptarchiv Koblenz), HAEK (Historisches Archiv des Erzbistums Köln), HStAD (Hauptstaatsarchiv Düsseldorf), BAT (Bistumsarchiv Trier), GStAPK (Geheimes Staatsarchiv Preußischer Kulturbesitz Berlin), AmrhKG (Archiv für mittelrheinische Kirchengeschichte). Contemporary spelling is kept in all quotes. Unless page numbers are mentioned, the archival material lacked pagination. In the use of 'superstition' in the following pages, no judgement of value is intended. Superstition is not meant as an instrument of historical analysis, merely as a rendition of contemporary positions.

2 Copy by Landrat von Platen to the Danzig provincial government of 10 Sep. 1836 [emphasis extant in the original], in GStAPK, I. HA, Rep. 77, Tit. 415, Nr. 39. A detailed summary of the Hela occurences can be found in Wilhelm Mannhardt, Die praktischen Folgen des Aberglaubens, mit besonderer Berücksichtigung der Provinz Preußen (Berlin, 1878), pp. 62-75.

3 See Judith Devlin, The Superstitious Mind: French Peasants and the Supernatural in the Nineteenth Century (New Haven and London, 1987); Eloïse Mozzani, Magie et superstitions de la fin de l'Ancien Régime à la Restauration (Paris, 1988); the review of these books by Eugen Weber, 'Religion and Superstition in Nineteenth Century France', Historical Journal 31 (1988) 399-423; Eva Labouvie, Verbotene Künste. Volksmagie und ländlicher Aberglaube in den Dorfgemeinden des Saarraumes (16. -19. century) (St Ingbert, 1992); Owen Davies, Witchcraft, Magic and Culture 1736-1951 (Manchester, 1999); Davies, A People Bewitched: Witchcraft and Magic in Nineteenth-Century Somerset (Bruton, 1999).

4. Recent research on superstition can be found in: Wolfgang Brückner, ' $\mathrm{Zu}$ den modernen Konstrukten "Volksfrömmigkeit" und "Aberglauben", Jahrbuch für Volkskunde 16 (1993) 215-22; Christoph Daxelmüller, Zauberpraktiken. Eine Ideengeschichte der Magie (Zurich, 1993); Dieter Harmening, 'Superstition - "Aberglaube"', in Dietz-Rüdiger Moser (ed.), Glaube im Abseits. Beiträge zur Erforschung des Aberglaubens (Darmstadt, 1992), pp. 368-401. A compilation of the literature is given in Martin Stute, Hauptzïge 
wissenschaftlicher Erforschung des Aberglaubens und seiner populärwissenschaftlichen Darstellungen der Zeit von 1800 bis in die Gegenwart. Eine Literaturanalyse (Frankfurt am Main, Berlin and Bern, 1997). Less recent, but still worth reading is Hermann Bausinger, 'Aufklärung und Aberglaube', Deutsche Vierteljahrsschrift für Literaturwissenschaft und Geistesgeschichte 37 (1963) 345-62.

5 As a rule, these publications merely described 'pre-modern' ideas, culminating in the most comprehensive folkloristic collection of superstitious ideas and practices, the Handwörterbuch des Deutschen Aberglaubens (HDA). See Hanns Bächtold-Stäubli (ed.), Handwörterbuch des deutschen Aberglaubens, unter besonderer Mitwirkung von Eduard Hoffmann-Krayer, 10 vols (Berlin and New York, 1987). Its most important precursor is Adolf Wuttke, Der deutsche Volksaberglaube der Gegenwart (3rd edn, Berlin, [1860] 1900).

6 Heinz Dieter Kittsteiner, 'Die Abschaffung des Teufels im 18. Jahrhundert. Ein kulturhistorisches Ereignis und seine Folgen', in Alexander Schuller and Wolfert von Rahden (eds), Die andere Kraft. Zur Renaissance des Bösen (Berlin, 1993), pp. 55-92.

7 Regierung Danzig to Rochow vom 7 Sep. 1836, in GStAPK, I. HA, Rep. 77, Tit. 415, Nr. 39.

8 Regierung Danzig to Rochow vom 4 Feb. 1837, in GStAPK, I. HA, Rep. 77, Tit. 415 , Nr. 39.

9 Regierung Danzig to Rochow vom 30 Sep. 1836, in GStAPK, I. HA, Rep. 77, Tit. 415 , Nr. 39.

10 Altenstein to Rochow vom 3 Dec. 1836, in GStAPK, I. HA, Rep. 77, Tit. 415, Nr. 39.

11 Generalvikariat Münster to Regierung Düsseldorf vom 27 Dec. 1836, in HStAD,Best. Regierung Düsseldorf, Nr. 226, Blatt 11 (Hexenglauben auf der Bönningharder Heide).

12 Justus von Olshausen, Kommentar zum Strafgesetzbuch für das Deutsche Reich. Nebst einem Anhang, enthaltend die Strafbestimmungen der Konkursordnung, 2 Bände, 10., umgearbeitete Aufl., Berlin 1916, hier Bd. 2, S. 1431-5. Innenministerium to Regierung Koblenz vom 14 Oct. 1873, in LHAK, Best. 441, Nr. 9481. Emphasis extant in the original.

13 Court protocol from 30 May 1837, in LHAK, Best. 441, Nr. 2858.

14. Compare Nils Freytag, 'Praxis zwischen "Wissenschaft" und "Aberglauben". Animalischer Magnetismus in Preußen in der ersten Hälfte des 19. Jahrhunderts', Medizin, Gesellschaft und Geschichte 15 (1996) 141-66.

15 An example from Württemberg of the continued coexistence of medical and spiritual therapy, as well as the medical and theological patterns of interpretation for illnesses in the first half of the nineteenth century, can be found in Doris Kaufmann, Aufklärung, bürgerliche Selbsterfahrung und die 'Erfindung' der Psychiatrie in Deutschland, 1770-1850 (Göttingen, 1995), pp. 78-89.

16 Copy by Oberpräsident Ingersleben to Regierung Koblenz, 29 Sep. 1827, in LHAK, Best. 491, Nr. 274.

17 Löhr to Hüsgen, 18 Jan. 1841, in HAEK, Generalia I 31, 4.

18 See several examples in Friedrich Everhard von Mering and Ludwig Reichert, Historische Nachrichten über Teufelsbanner, Wahrsager, Wundermenschen, Geisterseher und andere dergleichen ausserordentliche Erscheinungen in den Rheinlanden und Westfalen seit Beginn diesen Jahrhunderts. Bei Gelegenheit des Auftretens des Wunderdoctors Heinrich Mohren zu Niederempt nach meist noch unbenutzten und zuverlässigen Quellen bearbeitet (Cologne, 1843).

19 See Wahre Geschichte der Befreiung eines vom Teufel Besessenen. Ein sensationelles Ereigni $\beta$ aus unsern Tagen. Ausfïhrlich berichtet von einem Augenzeugen, 2. Aufl. (Aachen, 1887).

20 Jürgen Scheffler, 'Hexenglaube in der ländlichen Gesellschaft. Lippe im 19. und 20. Jahrhundert', in Gisela Wilbertz, Gerd Schwerhoff and Jürgen Scheffler (eds), 
Hexenverfolgung und Regionalgeschichte. Die Grafschaft Lippe im Vergleich (Bielefeld, 1994), pp. 263-96, evaluated newspapers and calendars containing several local examples from the county of Lippe. Danish examples from the eighteenth and nineteenth century are found in Gustav Henningsen, 'Das Ende der Hexenprozesse und die Fortsetzung der populären Hexenverfolgung', in Sönke Lorenz and Dieter R. Bauer (eds), Das Ende der Hexenverfolgung (Stuttgart, 1995), pp. 315-28. Examples from England can be found in Owen Davies, 'Methodism, the Clergy, and the Popular Belief in Witchcraft and Magic', History 82 (1997) 252-65.

21 The material of the Cologne Generalvikariat survives in HAEK, Generalia I 31.

22 Violations against the norms are to be understood as offences against informal as well as canonical precepts of varied importance for proper Catholic behaviour. See Irmtraud Götz von Olenhusen, Klerus und abweichendes Verhalten. Zur Sozialgeschichte katholischer Priester im 19. Jahrhundert. Die Erzdiözese Freiburg (Göttingen, 1994), pp. 143-5.

23 Extensively documented in Freytag, Aberglauben, pp. 57-65. Some examples from the theoretical literature are Hubert Theophil Simar, Der Aberglaube (Cologne, 1877); Franz Walter, Aberglaube und Seelsorge mit besonderer Berücksichtigung des Hypnotismus und Spiritismus (Paderborn, 1904); Joseph Fehr, Der Aberglaube und die katholische Kirche des Mittelalters. Ein Beitrag zur Kultur- und Sittengeschichte (Stuttgart, 1857).

24 As, for example, in Generalvikariat Köln to Landdechant Peter Bono (Erkelenz) vom 2 Dec. 1842, in HAEK, Generalia I 31, 5.

25 This method was also used, for example, in the case of the stigmatized Karoline Beller in Lüttgeneder in Westphalia, when the Paderborn diocese responsible for the village sent an episcopal commissioner. Compare Rudolf Muhs, 'Die Stigmata der Karoline Beller: Ein katholisches Frauenschicksal des Vormärz im Spannungsfeld von Volksreligiosität, Kirche, Staat und Medizin', in Irmtraud Götz von Olenhusen (ed.), Wunderbare Erscheinungen. Frauen und katholische Frömmigkeit im 19. und 20. Jahrhundert (Paderborn, 1995), pp. 83-130, especially pp. 109-21.

26 These quotes can be found in a letter from Amtgerichtsrates Granderat from Mettmann to Archbishop Philippus Krementz, 28 Jan. 1890; the letter from the clergymen Karl Löwing, Heinrich Hubert Hansen and Johann Wilhelm Otten of 21 Dec. 1889, in HAEK, Generalia I 31, 6, 1. The objects vomited by the woman were generally regarded as a manifestation of evil.

27 Dechant Heinrich Hubert Giersberg (Bedburdyck) to Generalvikariat Köln vom 23 Feb. 1889, in HAEK, Generalia I 31, 6, 1.

28 Compare Fischer's protocol of 20 Feb. 1890. Especially his remark of having been unable to distinguish whether 'he was dealing with conscious fraud or self-deception' is interesting; from this, we can conclude that an exorcism of the woman was not very likely to have been allowed.

29 Compare David Blackbourn, Wenn ihr sie wieder seht, fragt wer sie sei. Marienerscheinungen in Marpingen - Aufstieg und Fall des deutschen Lourdes (Reinbek bei Hamburg, 1997), pp. 324-33; original English edition, Marpingen: Apparitions of the Virgin Mary in Bismarkian Germany (Oxford, 1993).

30 Dechant Johann Franz Antwerpen (Deutz) to Generalvikar Johann Jacob Iven (Cologne) vom 1 March 1841, in HAEK, Generalia I 31, 4.

31 Copy by Bürgermeister Walldorf to Landrat Eberhard von Hymmen (Bonn) vom 4 Jan. 1826, in HAEK, Generalia I 31, 2.

32 Generalvikariat Köln to Philipps vom 12 March 1831, in HAEK, Generalia I 31,4.

33 On the Siegburg Asylum see Dirk Blasius, 'Einfache Seelenstörung'. Geschichte der deutschen Psychiatrie 1800-1945 (Frankfurt am Main, 1994), pp. 24-40; Christian Bradl, Anfänge der Anstaltsfürsorge für Menschen mit geistiger Behinderung ('Idiotenanstaltswesen'). 
Ein Beitrag zur Sozial- und Ideengeschichte des Behindertenbetreunngswesens am Beispiel des Rheinlands im 19. Jahrhundert (Frankfurt am Main, 1991).

34 Pfarrer Friedrich Friederici to Generalvikariat Köln vom 21 Aug. 1860, in HAEK, Generalia I 31, 4.

35 Compare Franz Bertrams, Heinrich Mohr, genannt 'der hl. Schäfer von Niederembt', masch. Manuskript, Niederembt 1925. In this compilation, details from the Dekanatsarchiv Bergheim and the parish archive of Niederembt that are no longer extant or findable have been evaluated.

36 The example of Bavarian Redemptorists can be found in Otto Weiss, 'Die Redemptoristen in Bayern (1790-1909). Ein Beitrag zur Geschichte des Ultramontanismus', phil. Diss. masch., 3 Bde., Munich 1977, 971-80 and 1170-88. More concisely: Ders., Seherinnen und Stigmatisierte, in Götz von Olenhusen, Wunderbare Erscheinungen, S. 51-82.

37 See Dechant Franz Alexander Halm to Generalvikariat Köln vom 7 May 1852, in HAEK, Generalia I 31, 6, 1.

38 For this compare Michael Felix Langenfeld, Bischöfliche Bemühungen um Weiterbildung und Kooperation des Seelsorgeklerus. Pastoralkonferenzen im deutschen Sprachraum des 19. Jahrhunderts (Rome, Freiburg and Vienna, 1997), pp. 442-58. Furthermore see Bernhard Schneider, 'Lesegesellschaften des Klerus im frühen 19. Jahrhundert. Ein Beitrag zur historischen Kommunikationsforschung', AmrhKG 49 (1997) 155-77; Rudolf Schlögl, Glaube und Religion in der Säkularisierung. Die katholische Stadt - Köln, Aachen, Münster - 1700-1840 (Munich, 1995), pp. 153-5.

39 Copy by Landrat Carl Gerhard von Gärtner (Ahrweiler) to Windeck vom 20 Sep. 1837, in LHAK, Best. 635, Nr. 407. Draft Regierung Koblenz to Gärtner vom 1 Sep. 1837, in LHAK, Best. 441, Nr. 9481.

40 See, for example, Friedrich Nippold, Die gegenwärtige Wiederbelebung des Hexenglaubens. Mit einem literarisch-kritischen Anhang über die Quellen und Bearbeitungen der Hexenprozesse (Berlin, 1875).

41 This reasoning, however, can no longer be considered valid for the time of the Prussian-German Kulturkampf in the Kaiserreich of 1871. Blackbourn, Wenn ihr sie wieder seht, p. 373, explains the excessive reactions of some local officials by stating that the Catholic belief in miracles was 'zutiefst wesensfremd' ('deeply contrary to the nature') of the Prussians.

42 About Gänsereiten: copy by Regierung Aachen to Polizeidirektor Coels vom 15 Dec. 1820 , in HStAD, Best. Landratsamt Erkelenz, Nr. 208. Reuessen und -trinken: Regierung Aachen to Ingersleben vom 30 May 1823, in LHAK, Best. 403, Nr. 953, S. 1-7. See also Gunther Hirschfelder, 'Reu- und Trauertrinken im Regierungsbezirk Aachen. Das Beispiel einer entgleisten Totenfeier im Jahre 1823', in Hildegard Mannheims, Georg Kehren and Peter Oberem (eds), Volkskundliche Grenzgänge. Festgabe der Schülerinnen und Schüler H. L. Cox zum 60 Geburtstag (Erkelenz, 1995), pp. 205-19. To learn about the Gebehochzeiten the Prussian administration consulted extensive material compiled by French officials between 1794 and 1814: Beilage E Unterpräfekt Arrondissement Hamm to Präfekt Ruhrdepartement vom 24 Jan. 1810, in GStA PK, I. HA, Rep. 77, Tit. 435, Nr. 7, Vol. I. About Brautfangen: Landrat Georg Bärsch (Prüm) to Regierung Trier vom 4 June 1830, in LHAK, Best. 442, Nr. 3768, Bl. 5.

43 Solms-Laubach to Landrat Joseph Freiherr von Weichs vom 24 July 1818; Weichs to Solms-Laubach vom 13 Aug. 1818, in HStAD, Best. Oberpräsidium Köln, Nr. 804, Bl. 3 und Bl. $4 \mathrm{r}-5 \mathrm{v}$. An Oberpräsident is the official in charge of a Regierungsbezirk.

44. See article 'Gewitter', in HDA, vol. 3, col. 815-33 Nikolaus Kyll, 'Die Glocke im Wetterglauben und Wetterbrauch des Trierer Landes', Rheinisches Jahrbuch für Volkskunde 9 (1958) 130-79. About the change in the perception of thunderstorms see Heinz Dieter Kittsteiner, Die Entstehung des modernen Gewissens (Frankfurt am Main, 
[1991] 1995), pp. 55-79. About the measures taken in the electorate of Trier see Andreas Heinz, 'Das Ende der "figurierten” Karfreitagsprozessionen im Kurfürstentum Trier unter Erzbischof Clemens Wenzeslaus (1768-1802)', AmrhKG 44 (1992) 177-88.

45 See Roy Porter, 'The Patient's View: Doing Medical History From Below', Theory and Society 14 (1985) 175-98.

46 Beilage der Allgemeinen Zeitung vom 24 Aug. 1836, in GStAPK, I. HA, Rep. 77, Tit. 415 , Nr. 39.

47 Questioning of the village mayor from 28 Aug. 1836. Beilage Nr. 5 zum Schreiben des Landrats Platen to Regierung Danzig vom 10 Sep. 1836, in GStAPK, I. HA, Rep. 77, Tit. 415 , Nr. 39.

48 From the perspective of medical history, exorcism is seen as an early form of therapy for neurotics and hysterics. In the present context, the main part of our attention is with the more varied contemporary views. See Robert Jütte, Geschichte der Alternativen Medizin. Von der Volksmedizin zu den unkonventionellen Therapien von heute (Munich, 1996), pp. 78-90. Still important is the study by Gustav Roskoff, Geschichte des Teufels, 2 vols (Leipzig, [1869] 1967). About the following, also compare Alfonso di Nola, Der Teufel. Wesen, Wirkung, Geschichte (Munich, 1990), pp. 329-57.

49 Andreas Heller, “'Du kommst in die Hölle ...". Katholizismus als Weltanschauung in lebensgeschichtlichen Aufzeichnungen’, in Therese Weber and Olivia Wiebel-Fanderl (eds), Religion und Alltag. Interdisziplinäre Beiträge zu einer Sozialgeschichte des Katholizismus in lebensgeschichtlichen Aufzeichnungen (Vienna and Cologne, 1990), pp. $28-54$.

50 Compare Wilhelm Heinrich Riehl, Land und Leute, 5. Aufl., Stuttgart/Augsburg 1861, S. 78f. On hostility towards technology during the nineteenth century see Rolf Peter Sieferle, Fortschrittsfeinde? Opposition gegen Technik und Industrie von der Romantik bis zur Gegenwart (Munich, 1984), pp. 87-117.

51 This collection, the provenance of which appears to be uncertain, cannot be dated precisely, although there appears to be a barely legible letter dated Pellingen, 6 June 1824 among the loose papers. In BAT, Best. 71, 43, Nr. 8, 8. Zitierte Beschwörungsformel. The omission is illegible in the original.

52 'Bethzairle, und allen bösen Geister, Menschengeister Luft, Wasser, Feuer Samen, Erd und alle Geister, ich N. verbiethe euch mein und meiner Kinder Bettstädte, ich verbiethe euch im Namen Gottes mein Haus Ställe Scheuer, mein, meiner Frau und meinen Kindern Blut und Fleisch, unser Leiber und Seelen, ich N. verbiete euch alle Löcher, ja gar Nägellöcher in meinem Haus, Ställen, Scheuer, überall meines Hauses, bis alle Berglein ... und alle Wässerlein wattelt, alle Blättlein, an den Bäumen zehlet, und alle Sterne am Himmel zehlet, bis, uns kommt der liebe Tag, wo die Hl. Maria Mutter Gottes ihren zweiten Sohn gebähret +++ Diese verbiethe ich euch im Namen der allerheiligsten Dreyfaltigkeit Gott Vater + Sohn + und Hl. Geist + Amen.'

53 See Benjamin Ziemann, 'Katholische Religiosität und die Bewältigung des Krieges. Soldaten und Militärseelsorger in der deutschen Armee 1914-1918', Jahrbuch für Friedensforschung 6 (1997) 116-36, especially 123-5.

54. See A. Mielay, Das Berliner Wunderkind. Ein Beitrag zur Tagesgeschichte nach vierzehntägigen genauesten Beobachtungen (Berlin, 1849), p. 12; Rudolf Leubuscher, 'Das Wunderkind in der Schifferstrasse', in Robert Jütte (ed.), Wege der Alternativen Medizin. Eine Lesebuch (Munich, 1996), pp. 97-100. See also Manfred Gailus, Strasse und Brot. Sozialer Protest in den deutschen Staaten unter besonderer Berücksichtigung Preußens 1847-1849 (Göttingen, 1990), p. 136; Rüdiger Hachtmann, Berlin 1848. Eine Politik- und Gesellschaftsgeschichte der Revolution (Bonn, 1997), p. 838f.

55 Compare Thomas Nipperdey, Deutsche Geschichte 1866-1918, Erster Bd.: Arbeitswelt und Bürgergeist (Munich, 1990), p. 225. 